\title{
PENGARUH DOSIS KOMPOS TONGKOL JAGUNG TERHADAP PRODUKTIVITAS BAWANG MERAH (Allium ascalonicum (L.))
}

\author{
(The Effect Of Corn Cob Compost Dosage On The Productivity Of Shallots \\ (Allium ascalonicum L.))
}

\author{
Akhmad Zulmy Assiddiqi, Sulistyawati, Retno Tri Purnamasari, Fajar Hidayanto \\ Program Studi Agroteknologi, Fakultas Pertanian, Universitas Merdeka Pasuruan \\ Jl. Ir. H, Juanda No. 68 Pasuruan 67129, Jawa Timur, Indonesia \\ Penulis Koresponden : diqi.zulmy@gmail.com
}

Article Submitted : 02-10-2021

Article Accepted : 18-01-2022

\begin{abstract}
This study aims to determine the effect of corn cobs compost on the productivity of shallots. The study was conducted from January to April 2021 in the rice fields of Pateguhan Village, Gondangwetan District, Pasuruan Regency. The soil used has a pH of 5.8 with a Corganic content of $2.41 \%$, N-total $0.17 \%, \mathrm{P}_{2} \mathrm{O}_{5} 38.46 \mathrm{ppm}$, and $\mathrm{K}_{2} \mathrm{O} 0,80 \mathrm{ppm}$. This study was arranged in a Randomized Block Design One factor with six replications is the design of this study because it was carried out in open land. The treatment doses of corncob compost were as follows: (1) P0 = without corncob compost (control), (2) P1 = corncob compost 10 tons.ha ${ }^{-1}$, (3) $\mathrm{P} 2$ = corncob compost 15 tons.ha $^{-1}$ and (4) P3 = corncob compost 20 tons.ha ${ }^{-1}$. The data obtained during the study were analyzed using analysis of variance ( $F$ test), if there was a significant effect then continued with the 5\% level BNT test. The results showed that the treatment of 20 ton.ha $^{-1}$ corncob compost gave the highest yield on the observed variables of plant height, number of leaves, leaf area, dry weight and tuber weight, but for the observation variable the highest number of tubers was in the control treatment. Treatment of corncob compost 20 tons.ha ${ }^{-}$ ${ }^{1}$ resulted in tuber weight of 8.74 tos.ha $^{-1}$, treatment of corncob compost 15 tons.ha $^{-1}$ resulted in

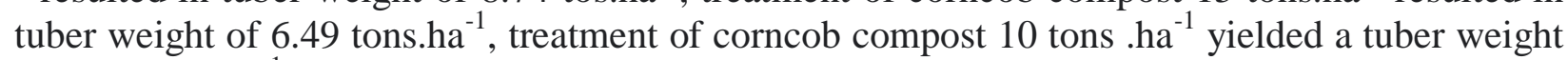
of 5.26 tons.ha $^{-1}$ and the lowest yield was found in the control treatment with a yield of 4.17 tons.ha- ${ }^{-1}$
\end{abstract}

Keywords: corn cob compost, yield, shallot

\section{PENDAHULUAN}

Tanaman hortikultura seperti bawang merah merupakan komoditas tanaman rempah-rempah yang selalu ada di pasar dan memiliki nilai ekonomi tinggi. Komoditas ini menjadi salah satu pilihan sebagai bahan penyedap makanan dan termasuk kelompok rempah yang berfungsi sebagai tanaman obat (Astuti et al. 2018).

Badan Pusat Stastistik Jawa Timur (2016) menjelaskan selama 2015 sampai 2016 produksi bawang merah mengalami penurunan sebesar 201.913 ton pada total luas lahan 27.013 hektar. Upaya peningkatan produktivtias bawang merah harus dilakukan dengan berbagai cara seperti memperbaiki metode dan teknologi budidaya serta penggunaan pupuk yang tepat dan berimbang. Pengaplikasian pupuk kimia dosis tinggi jika diteruskan secara tidak langsung akan mengakibatkan penurunan kesuburan dan kandungan bahan organik tanah. 
Ketergantungan terhadap pupuk kimia harus dikurangi dengan dengan menggunakan teknologi alternatif seperti pupuk organik (Nizar, 2011). Pemberian pupuk organik di dalam tanah akan menyebabkan peningkatan kemampuan tanah dalam menyediakan jumlah air dan berfungsi untuk menyediakan sumber energi bagi jasad mikro, sehingga jika tidak terdapat bahan organik yang cukup dalam tanah proses biokimia akan terhenti. Selain itu, kehadiran pupuk organik akan menjaga kesuburan dan kesehatan tanah. Sutanto (2002) berpendapat bahwa kondisi fisika tanah seperti aerasi dan agregat tanah akan menjadi lebih baik jika kandungan bahan organik cukup tinggi. Penelitian Laude dan Hadid (2007) menyebutkan bahwa sifat-sifat tanah pada lahan bawang merah akan menjadi lebih baik jika diberikan pupuk organik cair, berbeda dengan pupuk kimia yang dapat meninggalkan residu negatif terhadap lingkungan.

Saat ini dengan perkembangan teknologi yang ada, pembuatan pupuk organic dapat dilakukan dengan menggunakan berbagai macam bahan dasar, seperti limbah tanaman jagung. Jagung menjadi komoditas terbesar yang dibudidayakan petani setlah tanaman padi, sehingga hal ini juga menambah meningkatnya limbah tanaman jagung yang dihasilkan, terutama tongkol jagung. Tongkol jagung adalah limbah bagian buah jagung setelah biji dirontokkan. Menurut Faesal dan Syuryawati (2018) menyebutkan $70 \%$ dari total biomassa tanaman jagung merupakan limbah jagung yang dapat dimanfaatkan. Limbah ini sebenarnya bisa menjadi bahan yang dapat optimal namun sering hanya dibakar saja. Hersanti et al. (2017) berpendapat bahwa selama ini hasil sampingan dari tanaman jagung berupa tongkol dan daun jagung hanya digunakan untuk pakan ternak. Namun sebenarnya serasah tanaman jagung yang berlimpah dapat diubah bentuk dan fungsinya menjadi kompos. Serasah tersebut dapat dimanfaatkan sebagai kompos melalui proses dekomposisi selama kurang lebih satu sampai dua bulan.

Hasil analisis tanah awal lahan penelitian didapatkan hasil analisis nitrogen total cukup rendah dengan nilai $0,17 \%$, kandungan phosphor sangat tinggi dengan nilai 38,46\%, kandungan C-organik sedang dengan nilai 2,41, dan kandungan kalium tinggi dengan nilai $0,80 \%$. Berdasarkan hasil uji tersebut pemberian pupuk organik perlu dilakukan karena untuk mendukung dan memberikan hasil maksimal terhadap tanaman yang dibudidayakan.

\section{METODE PENELITIAN}

\section{Tempat dan Waktu}

Penelitian dilakukan bulan Januari hingga April 2021 di persawahan Desa Pateguhan Kecamatan Gondangwetan Kabupaten Pasuruan dengan rata-rata ketinggian tempat $15 \mathrm{mdpl}$ dan suhu antara 29-34 ${ }^{\circ} \mathrm{C}$. Hasil uji kualitatif menunjukkan tanah yang di lokasi penelitian adalah tanah inceptisol.

\section{Bahan dan Alat}

Bahan yang digunakan adalah pupuk NPK (16:16:16), kompos tongkol jagung, benih bawang merah varietas biru lanchor. Sedangkan cangkul, timbangan, cutter, gembor, $\mathrm{pH}$ meter, sprayer, timbangan analitik, gelas ukur, ember, kayu, alat pengering (oven), penggaris meupakan alat yang digunakan selama penelitian.

\section{Rancangan Penelitian}

Rancangan Acak Kelompok (RAK) satu faktor dengan enam ulangan merupakan rancangan penelitian ini karena dilakukan di lahan terbuka. Perlakuan pemberian dosis kompos tongkol jagung sebagai berikut: (1) $\mathrm{P}_{0}=$ tanpa kompos tongkol jagung (kontrol), (2) $\mathrm{P}_{1}=$ kompos tongkol jagung 10 ton.ha ${ }^{-1}$, (3) $\mathrm{P}_{2}=$ kompos tongkol jagung15 ton.ha ${ }^{-1}$ dan (4) $\mathrm{P}_{3}=$ kompos tongkol jagung 20 ton.ha' ${ }^{-1}$. 


\section{Variabel Pengamatan}

Variabel penelitian terdiri dari: (1) tinggi tanaman diukur dari permukaan tanah sampai ujung daun ditarik ke atas dan diluruskan., (2) jumlah daun didapatkan dengan cara menghitung daun berwarna hijau dan tumbuh sempurna, (3) luas daun dengan metode silinder pada setiap tanaman, (4) bobot kering bagian total tanaman, (5) jumlah umbi per petak dihitung dari jumlah umbi pada sampel panen yang dihasilkan setelah panen dan (6) bobot umbi per rumpun dihitung dari bobot umbi yang sudah dikeringanginkan pada sampel non destruktif yang dihasilkan setelah panen.

\section{Analisis Data}

Data yang diperoleh selama penelitian dianalisis dengan analisis ragam (Anova) selanjutnya apabila terdapat perlakuan yang menunjukkan perbedaan maka dilanjutkan dengan Uji BNT (Beda Nyata Terkecil) taraf 5\%.

\section{HASIL DAN PEMBAHASAN}

\section{Tinggi Tanaman}

Hasil analisis ragam menunjukkan perlakuan kompos tongkol jagung berpengaruh nyata terhadap rerata tinggi tanaman umur 14 HST dan umur 21, 28 dan 35 HST berpengaruh sangat nyata (Tabel 1).

Tabel 1. Rerata Tinggi Tanaman pada Semua Umur Pengamatan

\begin{tabular}{cccccccccc}
\hline \multirow{2}{*}{$\begin{array}{c}\text { Dosis Kompos Tongkol } \\
\text { Jagung }\end{array}$} & \multirow{2}{*}{ 14 HST } & & 21 & 28 & \multicolumn{2}{c}{35} \\
& & HST & HST & HST & \\
\hline Kontrol & 16,35 & a & 17,15 & a & 19,61 & a & 22,23 & a \\
10 ton.ha $^{-1}$ & 17,27 & a & 18,71 & ab & 20,99 & ab & 23,83 & ab \\
15 ton.ha $^{-1}$ & 17,42 & ab & 19,39 & b & 21,90 & b & 24,83 & bc \\
20 ton.ha & & 19,44 & b & 21,59 & c & 23,93 & c & 26,41 & c \\
\hline BNT 5\% & $\mathbf{2 , 0 6}$ & & $\mathbf{2 , 0 3}$ & & $\mathbf{1 , 9 9}$ & & $\mathbf{1 , 9 1}$ & \\
\hline
\end{tabular}

Keterangan: Angka-angka yang didampingi huruf yang sama pada kolom yang sama menunjukkan tidak berbeda nyata pada uji BNT 5\%

Tanaman umur 14 HST sampai 35 HST menunjukkan pada perlakuan kompos tongkol jagung 20 ton.ha ${ }^{-1}$ memiliki rerata tertinggi sedangkan perlakuan kontrol merupakan yang terendah. Pada umur 14 HST perlakuan kompos tongkol jagung 20 ton.ha ${ }^{-1}$ berbeda nyata dengan perlakuan kontrol dan kompos tongkol jagung 10 ton.ha ${ }^{-1}$ namun tidak berbeda nyata dengan perlakuan kompos tongkol jagung 15 ton. ha 1. Pada umur 21 dan 28 HST tinggi tanaman memberikan perbedaan yang sama yaitu perlakuan kompos tongkol jagung 20 ton.ha ${ }^{-}$ ${ }^{1}$ berbeda nyata dengan perlakuan kontrol, 10 dan 15 ton.ha ${ }^{-1}$, namun saat umur 35 HST tinggi tanaman perlakuan kompos tongkol jagung 20 ton.ha $^{-1}$ tidak berbeda nyata dengan perlakuan kompos tongkol jagung 15 ton.ha ${ }^{-1}$. Tinggi tanaman pada akhir masa pengamatan yaitu umur $35 \mathrm{HST}$ adalah $26,41 \mathrm{~cm}$ sedangkan perlakuan kontrol 22,23 $\mathrm{cm}$.

Perlakuan pupuk kompos tongkol jagung 20 ton.ha ${ }^{-1}$ menghasilkan nilai rerata tertinggi sebesar 26,41 ton.ha ${ }^{-1}$ di akhir masa pengamatan yaitu 35 HST. Peristiwa ini diduga karena adanya peranan penambahan bahan organik kompos tongkol jagung, sehingga dapat disimpulkan penambahan bahan organik dalam dosis tinggi dapat membantu tanaman untuk memenuhi kebutuhan unsur hara pada fase pertumbuhan vegetatif tanaman salah satunya yaitu tinggi tanaman. Sejalan dengan penelitian Marviana dan Utami (2014) bahwa kandungan nitrogen, fosfor 
dan kalium dalam kompos tongkol jagung sangat membantu pertumbuhan tanaman.

\section{Jumlah Daun}

Perlakuan kompos tongkol jagung berpengaruh sangat nyata pada semua umur pengamatan terhadap parameter jumlah daun (Tabel 2). Pertumbuhan bawang merah akibat aplikasi kompos tongkol jagung 20 ton.ha ${ }^{-1}$ dapat memberikan jumlah daun tertinggi pada semua umur pengamatan.

Tabel 2. Rerata Jumlah Daun pada Semua Umur Pengamatan

\begin{tabular}{ccccccccc}
\hline Dosis Kompos Tongkol & \multicolumn{7}{c}{ Jumlah Daun (Helai) } \\
\cline { 2 - 9 } Jagung & 14 HST & 21 HST & 28 HST & 35 HST \\
\hline Kontrol & 9,43 & a & 11,33 & a & 13,57 & a & 15,48 & a \\
10 ton.ha $^{-1}$ & 10,48 & ab & 12,76 & b & 15,05 & b & 17,02 & b \\
15 ton.ha $^{-1}$ & 10,69 & b & 14,24 & c & 16,50 & c & 18,60 & c \\
20 ton.ha $^{-1}$ & 12,86 & c & 15,36 & d & 17,43 & d & 19,38 & d \\
\hline BNT 5\% & $\mathbf{1 , 1 5}$ & & $\mathbf{0 , 2 3}$ & & $\mathbf{0 , 1 2}$ & $\mathbf{0 , 1 2}$ &
\end{tabular}

Keterangan: Angka-angka yang didampingi huruf yang sama pada kolom yang sama menunjukkan tidak berbeda nyata pada uji BNT 5\%

Menurut hasil penelitian Ginanjar et al. (2016), jumlah daun per rumpun tanaman akan meningkat jika diberikan kompos kulit jagung sebanyak 25 ton.ha $^{-1}$, namun hasil tersebut tidak berbeda nyata dengan perlakuan kompos jerami jagung sebanyak 20 ton.ha ${ }^{-1}$. Pembentukan daun berhubungan erat dengan banyaknya unsur hara yang mampu diserap tanaman, hal ini disebabkan karena unsur hara akan menjadi pendorong dalam pembentukan sel-sel baru tanaman, yang mana hal ini berkaitan dengan peranan daun sebagai organ penting tumbuhan untuk melakukan proses fotosintesis. Menurut Dwidjoseputro (1994) daun memiliki peran langsung dan tidak langsung di dalam semua fungsi yang ada di dalam tubuh tanaman.

\section{Luas Daun}

Pada Tabel 3. menunjukkan perlakuan kompos tongkol jagung berpengaruh sangat nyata terhadap luas daun pada semua umur pengamatan. Umur pengamatan 21-35 HST menunjukkan hasil paling tinggi terjadi pada perlakuan pemberian kompos tongkol jagung dengan dosis 20 ton.ha $^{-1}$. Hasil tersebut berhubungan dengan jumlah daun pada perlakuan kompos tongkol jagung yang sama akan menghasilkan nilai paling tinggi.

Tabel 3. Rerata Luas Daun pada Semua Umur Pengamatan

\begin{tabular}{|c|c|c|c|c|c|c|c|}
\hline \multirow{2}{*}{$\begin{array}{c}\text { Dosis Kompos Tongkol } \\
\text { Jagung }\end{array}$} & \multicolumn{7}{|c|}{ Luas Daun $\left(\mathrm{cm}^{2}\right)$} \\
\hline & $14 \mathrm{HST}$ & $21 \mathrm{HST}$ & & $28 \mathrm{HST}$ & & 35 HST & \\
\hline Kontrol & 9,66 & 11,45 & $\mathrm{a}$ & 17,00 & $\mathrm{a}$ & 29,28 & $\mathrm{a}$ \\
\hline 10 ton.ha ${ }^{-1}$ & 15,16 & 17,28 & b & 21,09 & $a b$ & 34,36 & $a b$ \\
\hline 15 ton.ha ${ }^{-1}$ & 15,79 & 20,64 & $\mathrm{c}$ & 29,68 & bc & 35,69 & b \\
\hline 20 ton.ha ${ }^{-1}$ & 17,12 & 21,57 & $\mathrm{c}$ & 37,88 & $\mathrm{c}$ & 39,38 & $\mathrm{~b}$ \\
\hline BNT $5 \%$ & tn & 2,02 & & 10,06 & & 5,19 & \\
\hline
\end{tabular}

Keterangan: Angka-angka yang didampingi huruf yang sama pada kolom yang sama menunjukkan tidak berbeda nyata pada uji BNT 5\% 
Jumlah daun yang tumbuh semakin banyak akan mengakibatkan semakin besar juga nilai luas daun yang diperoleh, begitupun luas daun yang dihasilkan memungkinkan daun mampu menyerap cahaya maupun karbondioksida secara optimal sehingga meningkatkan pula laju fotosintesis tanaman. Hal ini didukung penelitian Sirait (2008) yang menemukan adaptasi tanaman yang tumbuh di bawah naungan akan memiliki luas daun lebih besar dibanding yang tumbuh di lahan terbuka karena sebagai upaya untuk memaksimalkan penangkapan cahaya yang jumlahnya terbatas.

$$
\text { Isnaini, (2020) melaporkan }
$$

pertumbuhan dan perkembangan tanaman dipengaruhi oleh hasil fotosintesis. Salah satu hasil tersebut berupa amilum yang ditranslokasikan ke akar, daun dan batang.

\section{Bobot Kering Bagian Total Tanaman}

Pada Tabel 4. menunjukkan pengaruh perlakuan kompos tongkol jagung 20 ton.ha $^{-1}$ juga berbeda nyata dengan berbagai perlakuan lainnya di semua umur pengamatan. Pada akhir masa pengamatan yaitu 35 HST, perlakuan kompos tongkol jagung 20 ton.ha $^{-1}$ memiliki rerata bobot kering tertinggi sebesar 3,87 gram sedangkan terendah pada perlakuan kontrol sebesar 1,67 gram. Hal ini berbanding lurus dengan hasil pengamatan tinggi tanaman dan jumlah daun yang dihasilkan pada perlakuan kompos sebanyak 20 ton.ha ${ }^{-1}$.

Tabel 4. Rerata Bobot Kering Total Tanaman pada Semua Umur Pengamatan

\begin{tabular}{|c|c|c|c|c|c|c|c|c|}
\hline \multirow{2}{*}{$\begin{array}{l}\text { Dosis Kompos Tongkol } \\
\text { Jagung }\end{array}$} & \multicolumn{8}{|c|}{ Bobot Kering Total Tanaman (g) } \\
\hline & $14 \mathrm{HST}$ & & $21 \mathrm{HST}$ & & $28 \mathrm{HST}$ & & $35 \mathrm{HST}$ & \\
\hline Kontrol & 0,48 & $\mathrm{a}$ & 0,51 & $\mathrm{a}$ & 0,79 & $\mathrm{a}$ & 1,67 & $\mathrm{a}$ \\
\hline 10 ton.ha ${ }^{-1}$ & 0,53 & $\mathrm{a}$ & 0,61 & $a b$ & 0,83 & $\mathrm{a}$ & 1,83 & $\mathrm{a}$ \\
\hline 15 ton.ha ${ }^{-1}$ & 0,53 & $\mathrm{a}$ & 0,76 & $\mathrm{~b}$ & 0,91 & $\mathrm{a}$ & 2,58 & $\mathrm{~b}$ \\
\hline 20 ton.ha $^{-1}$ & 0,62 & $b$ & 0,93 & $\mathrm{c}$ & 1,20 & $\mathrm{~b}$ & 3,87 & $\mathrm{c}$ \\
\hline BNT 5\% & 0,09 & & 0,16 & & 0,12 & & 0,62 & \\
\hline
\end{tabular}

Keterangan: Angka-angka yang didampingi huruf yang sama pada kolom yang sama menunjukkan tidak berbeda nyata pada uji BNT 5\%.

Peningkatan nilai bobot kering bagian total tanaman bawang merah menunjukkan adanya proses pertumbuhan dan perkembangan sel dan jaringan yang terjadi pada tanaman. Begitupun dengan pernyataan Hendra et al. (2016) bahwa persatuan bobot biomassa tanaman merupakan hasil penyerapan unsur hara yang akan tercermin pada pertumbuhan dan bobot kering tanaman. Bobot kering tanaman yang semakin meningkat menunjukkan bahwa pertumbuhan tanaman dalam kondisi baik dengan keberadaan bahan organik berupa kompos tongkol jagung dalam tanah karena unsur hara esensial bagi tanaman bawang merah telah disediakan oleh bahan organik.

\section{Jumlah Umbi}

Umbi bawang merah merupakan umbi lapis yang berasal dari perubahan pangkal daun yang berubah bentuk dan fungsi. Pertumbuhan dan perkembangan umbi tersebut akan membentuk tunas baru lalu tumbuh besar dan dewasa membentuk umbi kembali (Rahayu \& Berlian, 2007). Pada Tabel 5. menunjukkan perlakuan kompos tongkol jagung berpengaruh sangat nyata pada jumlah umbi.rumpun ${ }^{-1}$ dan jumlah umbi.petak ${ }^{-1}$. 
Selain itu Tabel 5. menunjukkan hasil jumlah umbi.rumpun ${ }^{-1}$ tertinggi terdapat pada perlakuan kontrol dan hasil lebih rendah terdapat pada perlakuan kompos tongkol jagung 20 ton.ha $^{-1}$.

Tabel 5. Rerata Jumlah Umbi rumpun ${ }^{-1}$ dan jumlah umbi petak ${ }^{-1}$

\begin{tabular}{ccccc}
\hline $\begin{array}{c}\text { Dosis Kompos Tongkol } \\
\text { Jagung }\end{array}$ & \multicolumn{2}{c}{ Jumlah $_{\text {Umbi.Rumpun }}{ }^{-1}$} & \multicolumn{2}{c}{ Jumlah Umbi.Petak $^{-1}$} \\
\hline Kontrol & 5 & $\mathrm{~b}$ & 265,63 & $\mathrm{~b}$ \\
10 ton.ha $^{-1}$ & 4 & $\mathrm{a}$ & 263,75 & $\mathrm{~b}$ \\
15 ton.ha $^{-1}$ & 4 & $\mathrm{a}$ & 210,63 & $\mathrm{a}$ \\
20 ton.ha $^{-1}$ & 4 & $\mathrm{a}$ & 210,00 & $\mathrm{a}$ \\
\hline BNT 5\% & $\mathbf{0 , 5 5}$ & $\mathbf{1 0 , 2 6}$ & \\
\hline
\end{tabular}

Keterangan: Angka-angka yang didampingi huruf yang sama pada kolom yang sama menunjukkan tidak berbeda nyata pada uji BNT 5\%

ton.ha ${ }^{-1}$ tidak berbeda nyata dengan perlakuan kompos tongkol jagung 15 dan 10 ton. ha $^{-1}$. Pada jumlah umbi.petak ${ }^{-1}$ hasil lebih tinggi terdapat pada kontrol sebesar 265,63 tetapi tidak berbeda nyata dengan perlakuan kompos tongkol jagung 10 ton.ha ${ }^{-}$ ${ }^{1}$ sedangkan hasil lebih rendah terdapat pada perlakuan kompos tongkol jagung 20 ton.ha ${ }^{-}$ ${ }^{1}$ sebesar 210,00 tetapi tidak berbeda nyata dengan perlakuan kompos tongkol jagung 15 ton.ha ${ }^{-1}$. Puspitasari et al. (2013) menyebutkan kondisi tanah gambut yang memiliki kapasitas dan kekuatan jerapan rendah dapat ditingkatkan dengan penambahan kompos. Pemberian kompos tersebut akan meningkatkan nilai kejenuhan basa sehingga unsur hara mudah tersedia optimal untuk pertumbuhan tanaman.

\section{Bobot Umbi}

Pada Tabel 6. pada bobot umbi menunjukkan perlakuan kompos tongkol jagung berpengaruh sangat nyata pada bobot umbi.rumpun ${ }^{-1}$, bobot umbi.petak ${ }^{-1}$, dan bobot umbi.hektar ${ }^{-1}$. Jika dibandingkan dengan parameter jumlah umbi (Tabel 5) pada perlakuan kontrol menunjukkan hasil paling tinggi dibandingkan perlakuan pemberian kompos tongkol jagung, hal ini berbanding terbalik dengan nilai bobot umbi.

Tabel 6. Rerata Bobot Umbi Rumpun ${ }^{-1}$, Bobot Umbi Petak ${ }^{-1}$, Bobot Umbi ha ${ }^{-1}$

\begin{tabular}{|c|c|c|c|c|c|c|}
\hline \multirow{2}{*}{$\begin{array}{c}\text { Dosis Kompos } \\
\text { Tongkol Jagung }\end{array}$} & \multicolumn{2}{|c|}{$\begin{array}{l}\text { Bobot Umbi } \\
\text { Rumpun }^{-1}(\mathrm{~g})\end{array}$} & \multicolumn{2}{|c|}{$\begin{array}{l}\text { Bobot Umbi } \\
\operatorname{Petak}^{-1}(\mathrm{~g})\end{array}$} & \multicolumn{2}{|c|}{$\begin{array}{l}\text { Bobot Umbi } \\
\text { Hektar }^{-1} \text { (ton) }\end{array}$} \\
\hline & 15,89 & $\mathrm{a}$ & 834,38 & $\mathrm{a}$ & 4,17 & $\mathrm{a}$ \\
\hline 10 ton.ha $^{-1}$ & 20,35 & $\mathrm{~b}$ & 1052,50 & $\mathrm{~b}$ & 5,26 & $\mathrm{~b}$ \\
\hline 15 ton. ha $^{-1}$ & 24,59 & $\mathrm{c}$ & 1298,13 & $\mathrm{c}$ & 6,49 & $\mathrm{c}$ \\
\hline 20 ton.ha $^{-1}$ & 33,48 & $\mathrm{~d}$ & 1748,75 & $\mathrm{~d}$ & 8,74 & $\mathrm{~d}$ \\
\hline BNT 5\% & $\mathbf{0 , 3 0}$ & & 17,74 & & 0,09 & \\
\hline
\end{tabular}

Keterangan: Angka-angka yang didampingi huruf yang sama pada kolom yang sama menunjukkan tidak berbeda nyata pada uji BNT 5\% 
Bobot umbi hasil tertinggi terdapat pada perlakuan kompos sebanyak 20 ton.ha ${ }^{-}$ 1, dimana peran kompos adalah mampu mengikat unsur hara sehingga ketersediaan nutrisi tercukupi untuk pembentukan umbi. Hal ini dikarenakan semakin banyak umbi yang terbentuk maka persaingan ruang tumbuh dan unsur hara yang dibutuhkan untuk perkembangan umbi semakin besar, sehingga umbi yang dihasilkan juga berukuran kecil yang mana hal tersebut akan mengakibatkan bobot umbi menjadi rendah pula. Hasil penelitian Isnaini (2020), menjelaskan bahwa setiap rumpun yang memiliki jumlah umbi yang lebih banyak maka pertumbuhan umbi tidak maksimal karena adanya kompetisi penyerapan unsur hara.

Pada perlakuan pemberian kompos tongkol jagung 20 ton.ha $^{-1}$ menunjukkan hasil tertinggi pada perlakuan bobot umbi, hal ini diasumsikan hasil fotosintat yang dihasilkan difokuskan pada pembesaran umbi tanaman bawang merah yang mana pada perlakuan tersebut jumlah umbi paling sedikit dibandingkan dengan kontrol, sehingga umbi tidak mengalami persaingan ruang tumbuh maupun persaingan translokasi hasil fotosintat yang dihasilkan, selain itu peranan unsur phosphor di dalam pembentukan umbi sangat penting karena menurut pernyataan Ramadhan et al. (2018) bahwa, kandungan $\mathrm{P}_{2} \mathrm{O}_{5}$ yang tinggi dalam tanah menyebabkan proses pembentukan umbi dalam berjalan dengan baik.

\section{KESIMPULAN}

Penelitian ini menyimpulkan bahwa perlakuan kompos tongkol jagung mempengaruhi pertumbuhan dan hasil tanaman bawang merah. Perlakuan kompos tongkol jagung 20 ton.ha ${ }^{-1}$ memberikan hasil tertinggi pada variabel pengamatan tinggi tanaman, jumlah daun, luas daun, bobot kering dan bobot umbi, namun untuk variabel pengamatan jumlah umbi tertinggi pada perlakuan kontrol. Perlakuan kompos tongkol jagung 20 ton.ha $^{-1}$ menghasilkan bobot umbi 8,74 ton.ha ${ }^{-1}$, perlakuan kompos tongkol jagung 15 ton.ha ${ }^{-1}$ menghasilkan bobot umbi 6,49 ton.ha ${ }^{-1}$, perlakuan kompos tongkol jagung 10 ton.ha $^{-1}$ menghasilkan bobot umbi 5,26 ton.ha ${ }^{-1}$ dan hasil terendah terdapat pada perlakuan kontrol dengan hasil 4,17 ton.ha ${ }^{-1}$.

\section{DAFTAR PUSTAKA}

Astuti, K., Susilawati \& M. Sefrila. (2018). Karakter Pertumbuhan Tanaman Bawang Merah Pada Berbagai Komposisi Media Tanam. J. Hort. Indonesia. 9(3): 167-173.

Badan Pusat Statistik. (2016). Luas Panen, Produksi dan Produktivitas Bawang Merah. Jawa Timur: Badan Pusat Statistik. https://jatim.bps.go.id/subject/163/ hortikultura.html. Diakses pada tanggal 27 September 2021.

Dwidjoseputro. (1994). Pengantar Fisiologi Tumbuhan. Gramedia. Jakarta. 232 hal.

Faesal dan Syuryawati. (2018). Efektivitas Kompos Limbah Jagung Menggunakan Dekomposer Bakteri dan Cendawan pada Tanaman Jagung. Pangan. 27(2): 117-128.

Ginanjar, A., H. Yetti \& S. Yoseva. (2016). Pemberian Pupuk Tricho Kompos Jerami Jagung Terhadap Pertumbuhan dan Poduksi Bawang Merah (Allium ascalonicum L.). JOM Faperta. 3(1):1-11.

Hendra., S. Samudin \& M. Anshar. (2016). Analisis Pertumbuhan Tanaman Bawang Merah (Allium cepa L. Kelompok Aggregatum) Var Lembah Palu yang Diberikan Atonik serta Pupuk Organik Cair. $J$. Agroland. 23 (1): 50-54. 
Hersanti, L. Djaya, F. Widiantini, \& E. Yulia. (2017). Pemanfaatan Serasah Tanaman Jagung sebagai Kompos dan Pakan Ternak Ruminansia. Pengabdian Kepada Masyarakat. 1(3): 202-204.

Isnaini, I. N. (2020). Pengaruh Pemberian Hydrilla verticillata Sebagai Pupuk Hijau Terhadap Pertumbuhan dan Hasil Tanaman Bawang Merah (Allium ascalonicum L). Skripsi. Fakultas Pertanian Universitas Merdeka Pasuruan.

Laude, S. dan A. Hadid. (2007). Respon Tanaman Bawang Merah Terhadap Pemberian Pupuk Cair Organik Lengkap. Jurnal Agrisains. 8(3) : 140-146.

Marviana, D \& L.B. Utami. (2014). Respon Pertumbuhan Tanaman Terung (Solanum Melongena L.) Terhadap Pemberian Kompos Berbahan Dasar Tongkol Jagung dan Kotoran Kambing Sebagai Materi Pembelajaran Biologi Versi Kurikulum 2013. JUPEMASI-PBI. 1(1) : 2407-1269.

Nizar, M. (2011). Pengaruh Beberapa Jenis Bahan Organik Terhadap Pertumbuhan dan Hasil Padi Dengan Metode

SRI. http://faperta.unand.ac.id/solum/v081-03-p19-26.pdf. Diakses tanggal 25 September 2021.

Puspita, F., Hasman \& Hapsoh. (2017). Pertumbuhan dan Produksi Bawang Merah (Allium ascalonicum L.) dengan Pemberian Trichokompos Jerami Padi dan Kalium di Lahan Gambut. Jurnal Penelitian Fakultas Pertanian Universitas Riau. 4(1) : 115.

Rahayu dan N. V. A. Berlian. (2007). Bawang Merah. Penebar Swadaya. Jakarta.

Ramadhan, A.F. Nur., \& T. Sumarni. (2018). Respon Tanaman Bawang Merah (Allium ascalonicum L.) Terhadap Pupuk Kandang dan Pupuk Anorganik (NPK). J. Produksi Tanaman. 6(5) : 815-822.

Sirait, J. (2008). Luas Daun, Kandungan Klorofil dan Laju Pertumbuhan Rumput pada Naungan dan Pemupukan yang Berbeda. Loka Penelitian Kambing Potong. JITV. 13(2) : 109-116.

Sutanto, R. (2002). Penerapan Pertanian Organik. Yayasan Kanisius. Yogyakarta. 